\title{
PENERAPAN MODEL “BACA, TULIS, DAN BAGI” DALAM PENGUATAN LITERASI PADA MAHASISWA PENDIDIKAN GURU MADRASAH IBTIDAIYAH STAIN PAMEKASAN
}

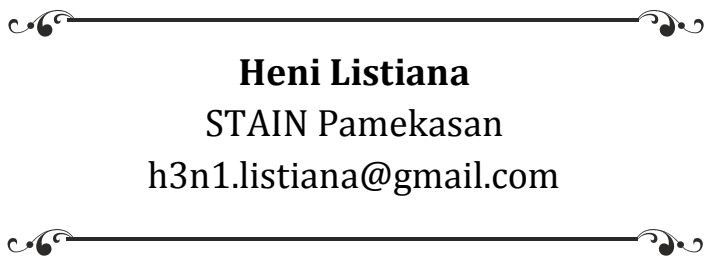

\begin{abstract}
Abstrak
Model baca, tulis, dan bagi adalah sebuah model untuk mengetahui kegiatan literasi yang dilakukan oleh mahasiswa. Penelitian ini menggunakan penerapan diari baca, diari menulis, dan diari berbagi. Dalam menggali data, penelitian ini menggunakan angket, dokumentasi, dan wawancara. Hasilnya penerapan ketiga diari tersebut diolah dengan menggunakan metode kuantitatif. Subyek penelitian ada 37 orang mahasiswa. Dalam mengerapkan model baca, tulis, dan bagi pada penguatan literasi mahasiswa terdiri dari tiga tahapan: kesatu, persiapan kedua, pelaksanaan, dan ketiga adalah analisis. Dalam waktu 30 menit mahasiswa memiliki kemampuan rata-rata membaca 25 halaman. Dan kemampuan menulis mahasiswa dalam waktu 30 menit adalah 10 paragraf. Setiap mahasiswa dalam kegiatan berbagi dapat menyampaikan pada rata-rata 3 orang.
\end{abstract}

Kata kunci: Literasi, Kemampuan literasi, Model Baca, Tulis, dan Bagi

Abstract
THE APPLICATION OF "READING, WRITING, AND DIVIDING"
MODELS IN STRENGTHENING LITERATION ON STUDENTSOF
ISLAMIC ELEMENTARY TEACHER EDUCATION IN STAIN
PAMEKASAN. Read, Write, dan Share Model is a model to know
literacy activities doing by high students. This research uses
implementing of Read diary, Write diary, and Share diary design. To
get the data, this research uses questionnaire, documentation, and
interview. Result of implementating the three diaries is processed by




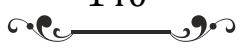

quantitative method. The subject are 37 student of teacher education elementary School subject. There are three steps to implement read, write, and share to strengthening of literacy. The first step, preparation the second step is implementation, and the third step is analys. The student's have reading capacity about 25 pages in 30 minutes. To write about 10 paragraphs they needs 30 minutes. Every students to share their information to 3 persons.

Keywords: Literacy, literacy capacity, Model of Read, Write, and Share

\section{A. Pendahuluan}

Tradisi membaca dan menulis mahasiswa adalah bagian yang tidak boleh diabaikan oleh Civitas Akademika. Sebagai rumah ilmu, perguruan tinggi harus menjadi tempat yang nyaman bagi mahasiswa untuk mempelajari, mengembangkan, dan memanfaatkan pengetahuan.Ketiga hal itu harus ditopang dengan tradisi baca-tulis atau literasi yang baik.

Namun, memperkuat tradisi literasi mahasiswa bukan pekerjaan mudah. Selain karena bangsa Indonesia mewarisi tradisi lisan yang lebih kuat, kini mahasiswa dihadapkan pada perubahan cara hidup yang radikal akibat arus besar digital. Cara manusia beraktivitas, berhubungan dengan manusia lain, dan tentu saja cara manusia memperoleh dan memperlakukan informasi telah berubah.Tapi belum ada perubahan signifikan terhadap kegiatan literasi.Hal ini dipengaruhi oleh kuatnya tradisi lisan di masyarakat Indonesia.Selain itu akses untuk melakukan kegiatan literasi juga masih belum mendukung.Oleh karenanya, menurut peneliti penting untuk membuat sebuah model literasi meningkatkan kemampuan mahasiswa.

Penelitian ini membahas tentang model baca, tulis, dan bagi serta bagaimana hasil dari implementasi model tersebut kepada mahasiswa. Peneliti kemudian memilih fokus penelitian pada Penerapan Model "Baca, Tulis dan Bagi" dalam Penguatan Literasi pada Mahasiswa Pendidikan Guru Madrasah Ibtidaiyah STAIN Pamekasan.

Penelitian ini menggunakan metode kuantitatif-kualitatif. Untuk menerapkan model baca, tulis dan bagi peneliti menggunakan 


$$
\text { recus }
$$

metode kualitatif dengan menerapkan diari yang harus diisi oleh subyek penelitian.Setelah itu data yang masuk dari diari tersebut dianalisis dengan menggunakan metode kuantitatif. Untuk menggali data dilakukan dengan mengolah data dari diari baca, diari menulis dan diari berbagi yang dilakukan oleh 37 orang mahasiswa.Data yang terkumpul kemudian diolah dan disajikan untuk mencari sebuah kesimpulan.

\section{B. Pembahasan}

\section{Model Baca, Tulis, dan Bagi}

Membaca adalah suatu cara untuk mendapatkan informasi dari sesuatu yang di tulis. Membaca melibatkan pengenalan simbol yang menyusun sebuah bahasa. Membaca dan mendengar adalah dua cara paling umum untuk mendapatkan informasi. Informasi yang didapat dari membaca dapat termasuk hiburan, khususnya saat membaca cerita fiksi atau humor.

Sebagian besar kegiatan membaca sebagian besar dilakukan dari kertas.Batu atau kapur di sebuah papan tulis bisa juga dibaca.Tampilan komputer dapat pula dibaca. Membaca dapat menjadi sesuatu yang dilakukan sendiri maupun dibaca keras-keras. Hal ini dapat menguntungkan pendengar lain, yang juga bisa membangun konsentrasi kita sendiri.

Membaca merupakan kegiatan yang membutuhkan keseimbangan yang baik, dimulai dari mulai gerakan mata dan pemantapan pemikiran serta kemampuan untuk menerima informasi dan menelaah informasi tersebut.

Saat melakukan kegiatan membaca butuh keseimbangan yang baik dan akurat agar kita mampu menerima informasi secara tepat dan mengingat informasi tersebut saat kita perlukan.Dalam membaca dibutuhkan pula kosentrasi agar kita bisa menyimpan informasi secara maksimal.Semakin sering kita membaca maka semakin baik pula kemampuan membaca kita.

Sebagai contoh fenomena di atas adalah minat anak terhadap bacaan yang sangat penting bagi anak-anak usia sekolah justru terkalahkan oleh minat anak terhadap televisi. Seharusnya membaca memiliki peranan penting dalam kehidupan anak, yaitu memperluas jaringan informasi, membuka wawasan kebudayaan, mewujudkan 


$$
\text { recus }
$$

kesinambungan, mendidik kepekaan rasa, dan membantu memecahkan kesulitan anak. Membaca dapat menanamkan nilai-nilai ilmu bagi anak dan keselarasan pribadi dengan masyarakatnya.

Kemampuan mambaca merupakan dasar untuk menguasai berbagai bidang studi. Jika anak pada usia sekolah permulaan tidak segera memiliki kemampuan membaca, maka ia akan mengalami banyak kesulitan dalam mempelajari berbagai bidang studi pada kelas-kelas berikutnya. Maka anak harus belajar membaca agar ia dapat membaca untuk belajar (Alfandi, 2016: 334-335).

Menulis adalah sebuah kegiatan menyalin bahasa lisan dalam bentuk huruf dan angka sehingga mengandung arti yang jelas.Kegiatan ini sebagai salah satu bentuk kegiatan komunikasi dan interaksi dalam masyarakat. Menulis juga menunjukkan arti pada kegiatan menyampaikan ide, gagasan, pikiran kepada orang lain dalam bentuk tulisan.

Berbagi adalah menyampaikan secara lisan informasi, ide, gagasan dan pikiran yang telah diikat, melalui kegiatan membaca dan menulis untuk memperkuat pemahaman seseorang.Kegiatan ini bertujuan menjadikan informasi itu tersimpan lebih lama di dalam otak seseorang.

Model Baca, Tulis dan Bagi adalah komposisi terpadu membaca, menulis, dan berbagi yang dilakukan dalam kegiatan mandiri dan kelompok.Model ini diharapkan dapat digunakan untuk seluruh pengembangan mata pelajaran/mata kuliah. Dalam rangka membaca dan menemukan ide pokok, pokok pikiran atau,tema sebuah wacana/kliping kemudian untuk mempertahankan makna yang didapat harus disampaikan kepada orang lain.

Model Baca, Tulis dan Bagi ini dapat dikategorikan pembelajaran terpadu. Berdasarkan sifat keterpaduannya, pembelajaran terpadu dapat dikelompokkan menjadi: model dalam satu disiplin ilmu yang meliputi model keterhubungan (connected) dan model terangkai (nested);model antar bidang studi yang meliputi model urutan (sequenced), model perpaduan (shared), model jaring laba-laba (webbed), model bergalur (theaded) dan model terpadu (integreted); model dalam lintas siswa.

Dalam Model Baca, Tulis dan Bagi, setiap mahasiswa bertanggung jawab terhadap tugas pribadi dan kelompok. Setiap 


$$
\text { r.c. } 143
$$

anggota kelompok saling mengeluarkan ide-ide untuk memahami suatu konsep dan menyelesaikan tugas (task), sehingga terbentuk pemahaman yang dan pengalaman belajar yang lama. Proses pembelajaran ini mendidik siswa berinteraksi sosial dengan lingkungan.

Prinsip belajar terpadu ini sejalan dengan empat pilar pendidikan yang digariskan UNESCO dalam kegiatan pembelajaran. Empat pilar itu adalah belajar untuk mengetahui (learning to know), belajar untuk berbuat (learning to do), belajar untuk menjadi diri sendiri (learning to be), dan belajar hidup dalam kebersamaan (learning to live together).

\section{Langkah - Langkah Model Baca, Tulis dan Bagi}

Agar lebih jelas model baca, tulis dan bagi dapat dijelaskan secara lebih rinci melalui langkah-langkah sebagai berikut:

a. Kegiatan Membaca

Membaca adalah suatu proses yang dilakukan serta digunakan oleh pembaca untuk memperoleh pesan yang disampaikan penulis melalui media bahasa tulis (Tarigan, 1984: 7). Pengertian lain dari membaca adalah suatu proses kegiatan mencocokkan huruf atau melafalkan lambang-lambang bahasa tulis.

Membaca adalah suatu kegiatan atau cara dalam mengupayakan pembinaan daya nalar (Tampubolon, 1987: 6). Dengan membaca, seseorang secara tidak langsung sudah mengumpulkan kata demi kata dalam mengaitkan maksud dan arah bacaannya yang pada akhirnya pembaca dapat menyimpulkan suatu hal dengan nalar yang dimilikinya.

Langkah kegiatan ini adalah:

1) Mahasiswa membaca setiap hari satu lembar dengan keajegan waktu.

2) Setelah empat hari mahasiswa meningkatkan menjadi kelipatan 3.

3) Satu minggu dilakukan evaluasi.

b. Kegiatan Menulis

Menulis dapat diartikan sebagai kegiatan menuangkan ide/gagasan dengan menggunakan bahasa tulis sebagai media penyampai.Menurut Tarigan (1986: 15) menulis berarti mengekpresikan secara tertulis gagasan, ide, pendapat, atau pikiran 


$$
\text { r.e. } 144
$$

dan perasaanjuga mengungkapkan pendapatnya mengenai menulis yaitu: meletakkan simbol grafis yang mewakili bahasa yang dimengerti orang lain.

Menulis dapat dianggap sebagai suatu proses maupun suatu hasil. Menulis merupakan kegiatan yang dilakukan oleh seseorang untuk menghasilkan sebuah tulisan.Menurut Heaton dalam Slamet (2008: 141) menulis merupakan keterampilan yang sukar dan kompleks.

Langkah kegiatan ini adalah:

1) Mahasiswa menuliskan hal-hal menarik dari bacaan yang dibaca setiap harinya pada sebuah buku catatan.

2) Mahasiswa mengumpulkan catatan tersebut sebagai bahan untuk berbagi dengan teman lainnya.

c. Kegiatan berbagi

Langkah kegiatan ini adalah:

1) Mahasiswa berkumpul untuk menyampaikan catatan hariannya kepada teman.

2) Mahasiswa saling bertanya dan berdiskusi tentang buku catatan tersebut.

\section{Penerapan model baca tulis dan bagi}

Kegiatan Membaca

Tahap 1: Persiapan

a. Memilih mahasiswa yang akan diikutkan dalam kegiatan penerapan model ini. Kegiatan ini penting untuk mendapatkan hasil yang baik.

b. Setiap mahasiswa menuliskan nama-nama yang bersedia mengikuti kegiatan ini.

c. Peneliti memilih peserta yang dapat ikut dalam kegiatan ini

d. Peneliti mempertimbangkan beberapa aspek psikologis, fisik, dan keseriusan mahasiswa

e. Peneliti menetapkan subyek penelitian

Tahap 2: Pelaksanaan

a. Subyek penelitian diberikan perlakuan sesuai dengan prosedur yang dibuat.

b. Pada tahap ini subyek penelitian diberikan diari membaca sebagai pemandu dalam pelaksanaan kegaiatan membaca sehari-hari. 


$$
\text { recus } 145
$$

Penulisan waktu dan jumlah halaman yang dibaca menjadi hal yang sangat penting untuk mengetahui peningkatan keterampilan membaca oleh subyek penelitian. Setiap subyek penelitian diharapkan menuliskan data sesuai dengan kenyataan yang ada. Hal ini bertujuan untuk mencapai keshohihan data sebagai bagian dari evaluasi.

\section{Gambar 1. Diary baca}

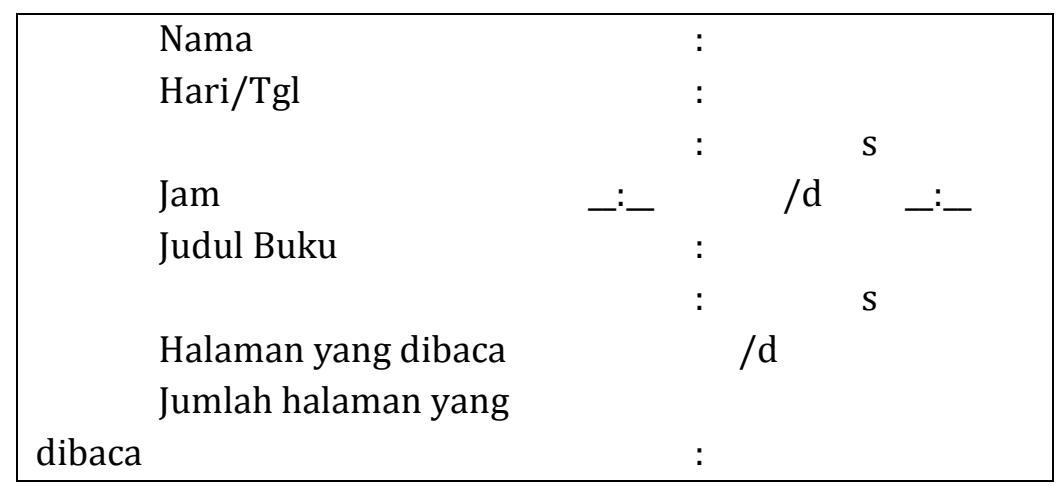

c. Subyek penelitian memilih satu buku yang diminati baik berupa buku fiksi atau non fiksi. Hal ini bertujuan untuk memberi ruang kepada subyek penelitian bisa mengikuti kegiatan ini dengan senang, karena mereka membaca sesuai dengan kecenderungan buku bacaan yang mereka minati.

d. Setelah itu data dianalisis untuk melihat hasilnya.

Tahap 3: Analisis

a. Diari baca yang telah diisi oleh subyek penelitian dianalisis

b. Hasilnya akan dituliskan dalam penelitian ini

Kegiatan Menulis

Tahap 1: Persiapan

a. Subyek penelitian yang terpilih melanjutkan tahap berikutnya

b. Subyek penelitian diberikan buku diari menulis

Tahap 2: Pelaksanaan

a. Pada tahap ini subyek penelitian diberikan catatan harian sebagai pemandu dalam pelaksanaan kegaiatan menulis sehari-hari. Subyek penelitian diharapkan mengisi jam pelaksanaan diari menulis ini. 
Gambar 2: buku diari menulis

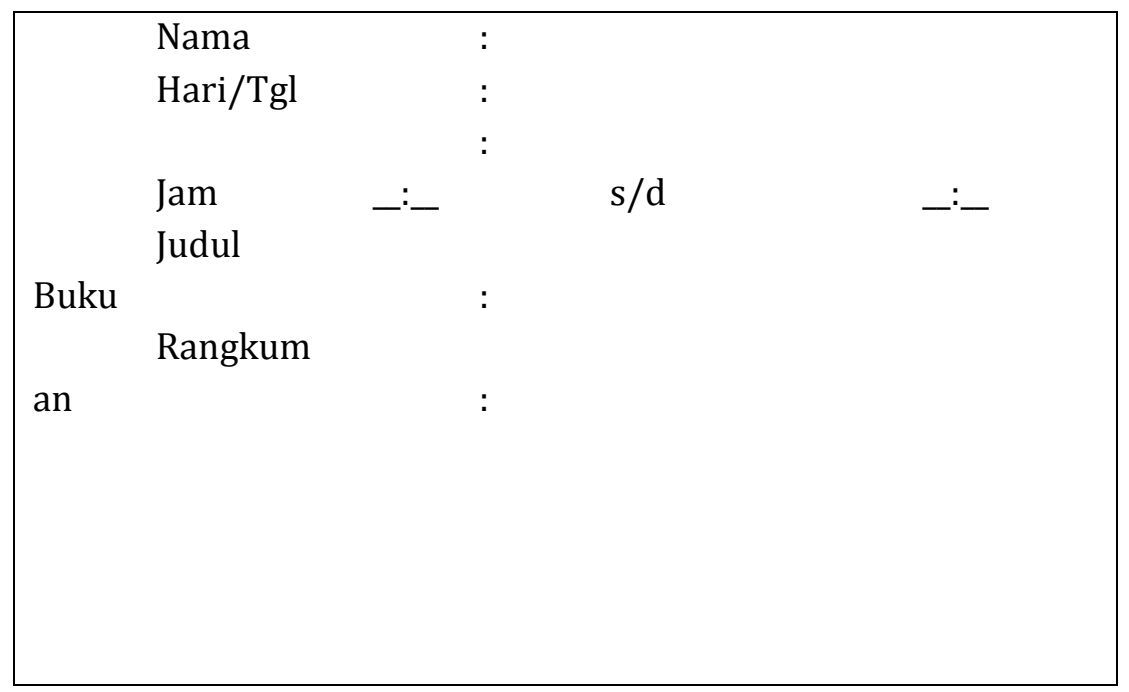

b. menulis/merangkum hasil bacaannya.

c. Setelah itu diobservasi untuk melihat hasilnya.

Tahap 3: Analisis

a. Setelah terkumpul buku diari menulis yang telah diisi subyek penelitian di analisis

b. Hasilnya akan dituliskan dalam penelitian ini

Kegiatan Berbagi

Tahap 1: Persiapan

a. Subyek penelitian yang terpilih melanjutkan tahap berikutnya

b. Subyek penelitian diberikan buku diari berbagi

Tahap 2: Pelaksanaan

a. Pada tahap ini subyek penelitian diberikan catatan harian sebagai pemandu dalam pelaksanaan kegaiatan berbagi sehari-hari.

b. Subyek penelitian menuliskan hasil respon dari teman-teman yang mereka ajak untuk berbagi yang terbagi dalam respon positif dan negatif. 


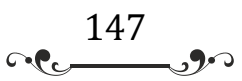

Gambar 3: buku diari berbagi

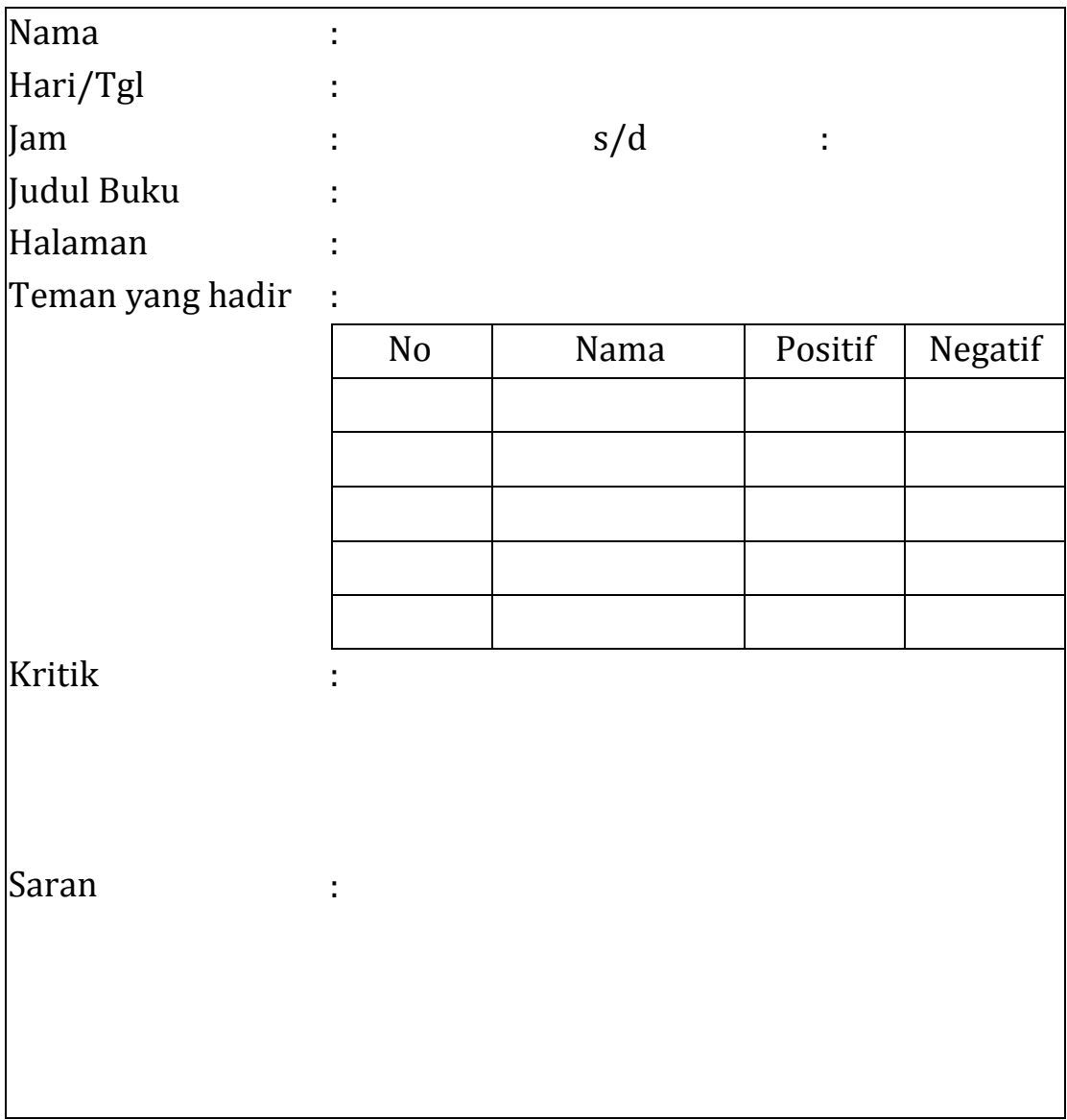

Diatas adalah prosedur yang dihasilkan dari penelitian tentang model baca tulis dan bagi dalam penguatan literasi bagi mahasiswa.

\section{Hasil Penerapan Model Baca, Tulis dan Bagi}

Berdasarkan hasil penyebaran instrumen buku diari membaca, menulis, dan berbagi dapat dijelaskan sebagai berikut:

a. Analisis Hari Pertama

Pada hari pertama subyek penelitian diberikan diari membaca dan menulis sebagaimana gambar 1 dan gambar 2 di atas. Tujuan diberikannya diari baca dan tulis bersamaan adalah: 


$$
\text { recos }
$$

1) Subyek penelitian lebih mudah untuk membaca kemudian dilanjutkan menulis hasil bacaannya pada satu waktu yang berdekatan

2) Dengan segera menulis, subyek penelitian tidak lupa terhadap bacaannya

3) Efektifitas waktu untuk mencapai hasil yang maksimal.

Berdasarkan hasil analisis di atas, pada hari pertama sebanyak 37 subyek penelitian telah membaca dalam waktu 1860 menit atau setara dengan $31 \mathrm{jam}$. Artinya rata-rata mahasiswa menghabiskan 50,27 menit untuk membaca. Dengan 37 judul buku yang berbeda subyek penelitian sudah membaca 935 halaman. Dengan tingkat rata-rata bacaan adalah 25,97 halaman. Artinya subyek penelitian membaca 25,97 halaman dalam waktu 50,27 menit.

Pada diari menulis terlihat jelas bahwa subyek penelitian menghabiskan waktu sebanyak 1071 menit atau setara dengan 17,85 jam. Rata-rata waktu yang dibutuhkan adalah 28,94 menit. Dengan jumlah tulisan yang dihasilan adalah 135 paragrap.Rata-rata subyek penelitian menghasilkan 3 paragrap. Artinya rata-rata setiap subyek penelitian menghasilkan 3 paragrap dalam waktu 28,94 menit.

Waktu paling lama membaca adalah 192 menit dan paling sedikit adalah 5 menit.Artinya dengan rentang yang jauh ini ada selisih yang jauh yaitu 187 menit.Artinya ada subyek penelitian yang bisa menghabiskan berjam-jam untuk membaca ada subyek yang hanya mampu bertahan membaca dalam waktu 5 menit. Berikut sebaran data berdasarkan rentangan waktu baca:

\begin{tabular}{|l|l|}
\hline Waktu & Orang \\
\hline $0-30$ menit & 18 orang \\
\hline $31-60$ menit & 9 orang \\
\hline $61-120$ & 8 orang \\
\hline 121 & 2 orang \\
\hline Jumlah & 37 orang \\
\hline
\end{tabular}




\section{res}

Data di atas menjelaskan bahwa kecenderungan membaca orang bisa bertahan pada level 0-30 menit pertama sebanya 18 orang. Sebanyak 9 orang mampu membaca selama 31-60 menit, dan 8 orang mampu membaca selama 61-120 menit. Dan hanya ada 2 orang yang bisa membaca lebih dari 121 menit atau lebih dari 2 jam.

Data ini menunjukkan bahwa selanjutnya dipilih kecenderungan bahwa kegiatan membaca ini maksimal 30 menit setiap harinya.Karena lebih dari 30 menit dimungkinkan orang sudah tidak konsentrasi untuk membaca.

Data di atas menjelaskan bahwa jumlah halaman yang paling banyak adalah 200 halaman dan paling sedikit adalah 1,5 halaman. Diketahui bahwa meskipun kedua subyek itu membaca buku fiksi tetapi jumlah halaman yang dibaca jauh berbeda.

Sementara persebaran data berdasarkan rentangan halaman (per sepuluh halaman) yang dibaca.Sebanyak 17 orang mampu membaca 1-10 halaman, sementara 11 orang mampu membaca 1120 halaman, 2 orang mampu membaca 21-30 halaman, 3 orang mampu membaca 31-40 halaman 1 orang mampu membaca 41-50 halaman dan 3 orang mampu membaca $>51$ halaman. Artinya kecenderungan orang mampu membaca 10 halaman.Rata-rata orang mampu bertahan membaca selama 30 menit maka jumlah halaman yang dibaca reratanya ada 10 halaman.Untuk membaca 1 halaman dibutuhkan waktu 3 menit.

Berbeda dengan dengan sebaran data tentang efektivitas membaca, yaitu selisih jumlah satuan waktu yang digunakan dengan jumlah halaman yang dibaca. Semakin sedikit waktu yang digunakan untuk membaca halaman maka akan semakin efektif. Ada subyek penelitian yang mampu membaca 35 halaman dalam waktu sepuluh menit atau keefektifannya berada pada 0,28 menit. Tetapi ada juga subyek penelitian yang hanya mampu membaca 1,5 halaman dalam waktu 60 menit artinya untuk menghabiskan 1 halaman dibutuhkan waktu sebanyak 20 menit.

Data di atas menunjukkan bahwa waktu paling lama untuk menulis adalah 62 menit atau setara dengan 1 jam lebih 2 menit.Sementara waktu paling pendek adalah 13 menit. Sementara sebaran data berdasarkan rentang waktu dapat dijelaskan sebagai berikut: 


\begin{tabular}{|c|c|}
\hline Waktu & Jumlah \\
\hline $0-20$ menit & 3 orang \\
\hline 21-40 menit & 30 orang \\
\hline 41-60 menit & 3 orang \\
\hline$>61$ menit & 1 orang \\
\hline Jumlah & 37 orang \\
\hline
\end{tabular}

Data di atas menjelaskan bahwa subyek penelitian yang mampu menulis pada rentang waktu 0-20 menit adalah 3 orang. Sementara yang mereka yang mampu menulis pada rentang 21-40 menit sebanyak 30 orang dan yang memiliki kemampun menulis dalam rentang 41-60 adalah 3 orang, serta yang bisa menulis lebih dari 61 menit adalah 1 orang.

Ada subyek penelitian yang mampu menulis 15 paragrap da ada beberapa yang menulis satu paragrap.Ada rentang yang jauh dengan selisih 14 paragrap.

Sebaran data bedasarkan jumlah paragrap yang dihasilkan dalam rentangan 5 adalah sebagai berikut:

\begin{tabular}{|l|l|}
\hline Banyak paragrap & Jumlah orang \\
\hline 1-5 paragrap & 32 orang \\
\hline 6-10 paragrap & 4 orang \\
\hline$>10$ paragrap & 1 orang \\
\hline Jumlah & 37 orang \\
\hline
\end{tabular}

Sebanyak 32 orang mampu menulis 1-5 paragrap dan 4 orang mampu menulis 6-10 paragrap serta hanya 1 orang yang bisa menulis lebih dari 10 paragrap. Artinya kecenderungan subyek penelitian bisa menulis maksimal 5 paragrap.Berdasarkan jumlah lama waktu menulis dibandingkan dengan banyak paragrap yang dihasilkan dapat diambil kesimpulan, kecenderungan subyek penelitian mampu menghabiskan waktu menulis selama 21-40 menit dan jumlah paragrap yang dihasilakan adalah 1-5 paragrap. 


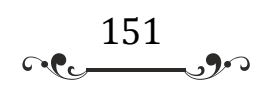

b. Analisis Hari Kedua

Pada hari kedua sebanyak 37 subyek penelitian telah membaca dalam waktu 1922 menit atau setara dengan 32,03 jam. Artinya rata-rata mahasiswa menghabiskan 51,94 menit untuk membaca. Dengan 37 judul buku yang berbeda subyek penelitian sudah membaca 1329 halaman. Dengan tingkat rata-rata banyak halaman adalah 35,91 halaman. Artinya subyek penelitian membaca 35,91 halaman dalam waktu 51,94 menit.

Pada diari menulis terlihat jelas bahwa subyek penelitian menghabiskan waktu sebanyak 1073 menit atau setara dengan 17,88 jam. Rata-rata waktu yang dibutuhkan adalah 29 menit.Dengan jumlah tulisan yang dihasilan adalah 102 paragrap. Rata-rata subyek penelitian menghasilkan 2,75 paragrap. Artinya rata-rata setiap subyek penelitian menghasilkan 2,75 paragrap dalam waktu 29 menit.

Berikut sebaran data berdasarkan urutan jumlah waktu membaca yang paling lama (dalam hitungan menit). Waktu paling lama membaca adalah 270 menit dan paling sedikit adalah 10 menit.Artinya dengan rentang yang jauh ini ada selisih yang jauh yaitu 260 menit.Artinya ada subyek penelitian yang bisa menghabiskan berjam-jam untuk membaca ada subyek yang hanya mampu bertahan membaca dalam waktu 5 menit.Berikut sebaran data berdasarkan rentangan waktu baca.

\begin{tabular}{|l|l|}
\hline Waktu & Orang \\
\hline $0-30$ menit & 18 orang \\
\hline $31-60$ menit & 10 orang \\
\hline $61-120$ & 7 orang \\
\hline$>121$ & 2 orang \\
\hline Jumlah & 37 orang \\
\hline
\end{tabular}

Data di atas menjelaskan bahwa kecenderungan membaca orang bisa bertahan pada level 0-30 menit pertama sebanya 18 orang. Data ini masih sama dengan hasil pada analisis hari pertama. Sebanyak 10 orang mampu membaca selama 31-60 menit.Angka ini 


\section{reces}

naik 1 orang bila dibandingkan dengan analisis hari pertama.Ada 7 orang mampu membaca selama 61-120 menit.Angka ini menurun bila dibandingkan dengan analisis hari pertama. Dan hanya ada 2 orang yang bisa membaca lebih dari 121 menit atau lebih dari 2 jam. Angka ini masih sama seperti pada hasil analisis hari pertama.

Peneliti masih berkeyakinan kecenderungan kegiatan membaca ini maksimal 30 menit setiap harinya.Karena lebih dari 30 menit dimungkinkan orang sudah tidak konsentrasi untuk membaca. Jumlah halaman yang paling banyak dibaca adalah 278 halaman dan paling sedikit adalah 1 halaman. ada perbedaan pada analisis hari pertama diperoleh jumlah halaman paling banyak adalah 200 halaman. Artinya ada peningkatan 78 halaman. Sementara pada jumlah halaman paling sedikit dibaca adalah 1 halaman ada penurunan 0,5 bila dibandingkan analisis hari pertama.

Persebaran data berdasarkan rentangan halaman (per sepuluh halaman) yang dibaca.Sebanyak 20 orang mampu membaca 1-10 halaman, ada peningkatan sebanyak 3 orang disbanding analisis hari pertama.sementara ada penurunan yang tajam pada level 11-20 halaman dari 11 orang menjadi 5 orang. Pada analisis hari pertama hanya ada 2 orang mampu membaca 21-30 halaman.Pada analisis hari kedua ada 3 orang mampu membaca 21-30 halaman. Data yang sama dengan analisis hari pertama 3 orang mampu membaca 31-40 halaman. Tidak ada orang mampu membaca 41-50 halaman, berbeda pada analisis hari pertama ada 1 orang. 6 orang mampu membaca $>$ 91 halaman.Artinya kecenderungan orang mampu membaca 10 halaman, sesuai dengan kesimpulan pada hari pertama.

Berdasarkan pemaparan di atas, dapat ditarik kesimpulan bahwa rata-rata orang mampu bertahan membaca selama 30 menit maka jumlah halaman yang dibaca reratanya ada 10 halaman.Untuk membaca 1 halaman dibutuhkan waktu 3 menit.

Berbeda dengan dengan sebaran data tentang efektivitas membaca, yaitu selisih jumlah satuan waktu yang digunakan dengan jumlah halaman yang dibaca. Semakin sedikit waktu yang digunakan untuk membaca halaman maka akan semakin efektif.

Data di atas menjelaskan bahwa ada subyek penelitian yang mampu membaca 176 halaman dalam waktu 80 menit atau keefektifannya berada pada 0,45 menit. Ada penurunan keefektifan 


$$
\text { reces }
$$

ini sebanyak 0,16 menit dibanding analisis hari pertama. Subyek penelitian yang membaca 1 halaman dalam waktu 20 menit sama dengan analisis hari pertama.

Berbeda dengan diari baca, diari menulis ini berdasarkan jumlah waktu lama menulis bahwa waktu paling lama untuk menulis adalah 80 menit atau setara dengan 1 jam lebih 20 menit. Sementara waktu paling pendek adalah 5 menit.Ada waktu lebih lama untuk menulis dengan analisis data yang pertama yaitu 19 menit lebih lama.Jumlah waktu paling pendek menulis selisih 8 menit lebih pendek dari analisis data yang pertama.

\begin{tabular}{|l|l|}
\hline \multicolumn{1}{|c|}{ Waktu } & Jumlah \\
\hline $0-20$ menit & 16 orang \\
\hline $21-40$ menit & 13 orang \\
\hline $41-60$ menit & 7 orang \\
\hline$>61$ menit & 1 orang \\
\hline Jumlah & 37 orang \\
\hline
\end{tabular}

Data di atas menjelaskan bahwa subyek penelitian yang mampu menulis pada rentang waktu 0-20 menit adalah 16 orang.Angka ini meningkat tajam sebanyak 13 angka. Ada dua kemungkinan yang terjadi:

1) Subyek penelitian sudah mulai terbiasa menulis sehingga membutuhkan waktu lebih cepat.

2) Subyek penelitian sudah enggan menulis dalam waktu yang panjang.

Sementara yang mereka yang mampu menulis pada rentang 21-40 menit sebanyak 13 orang.Angka ini menurun dari angka sebelumnya sebanyak 17 angka.Subyek penelitian yang memiliki kemampun menulis dalam rentang 41-60 adalah 7 orang, meningkat 4 angka.Hal ini bisa dimaknai ada subyek penelitian yang mulai menyukai menulis.Serta yang bisa menulis lebih dari 61 menit adalah 1 orang. Data ini sama dengan data sebelumnya.

Jumlah paragraf yang dihasilkan dalam rentangan 5 adalah sebagai berikut: 


\begin{tabular}{|l|l|}
\hline \multicolumn{2}{|c}{154} \\
\hline Banyak paragrap & Jumlah orang \\
\hline 1-5 paragrap & 37 orang \\
\hline Jumlah & 37 orang \\
\hline
\end{tabular}

Berbeda jauh dengan analisis hari pertama yang lebih bervariasi pada analisis hari kedua subyek penelitian hanya menulis pada rentangan tidak mencapai 5 paragraf.

Berdasarkan jumlah lama waktu menulis dibandingkan dengan banyak paragrap yang dihasilkan dapat diambil kesimpulan.Kecenderungan subyek penelitian mampu menghabiskan waktu menulis selama 0-20 menit dan jumlah paragrap yang dihasilakan adalah 1-5 paragrap.

c. Analisis Hari Ketiga

Berdasarkan hasil analisis pada hari ketiga sebanyak 37 subyek penelitian telah membaca dalam waktu 1657 menit atau setara dengan 27,61 jam. Artinya rata-rata mahasiswa menghabiskan 44,78 menit untuk membaca. Dengan 37 judul buku yang berbeda subyek penelitian sudah membaca 894 halaman. Dengan tingkat rata-rata banyak halaman adalah 24,16 halaman. Artinya subyek penelitian membaca 24,16 halaman dalam waktu 27,61 menit.

Pada diari menulis terlihat jelas bahwa subyek penelitian menghabiskan waktu sebanyak 1109 menit atau setara dengan 18,48 jam. Rata-rata waktu yang dibutuhkan adalah 29,97 menit. Dengan jumlah tulisan yang dihasilan adalah 97 paragrap. Rata-rata subyek penelitian menghasilkan 2,6 paragrap. Artinya rata-rata setiap subyek penelitian menghasilkan 2,6 paragrap dalam waktu 29,97 menit.

Berikut sebaran data berdasarkan urutan jumlah waktu membaca yang paling lama (dalam hitungan menit) adalah 240 menit dan paling sedikit adalah 5 menit. Artinya dengan rentang yang jauh ini ada selisih yang jauh yaitu 235 menit.Artinya ada subyek penelitian yang bisa menghabiskan berjam-jam untuk membaca ada subyek yang hanya mampu bertahan membaca dalam waktu 5 menit. Berikut sebaran data berdasarkan rentangan waktu baca: 


\begin{tabular}{|l|l|}
\hline Waktu & Orang \\
\hline $0-30$ menit & 21 orang \\
\hline $31-60$ menit & 9 orang \\
\hline $61-120$ & 6 orang \\
\hline$>121$ & 1 orang \\
\hline Jumlah & 37 orang \\
\hline
\end{tabular}

Data di atas menjelaskan bahwa kecenderungan membaca orang bisa bertahan pada level 0-30 menit pertama sebanya 21 orang. Data ini masih sama dengan hasil pada analisis hari pertama dan kedua, yaitu 21 orang. Angka ini naik 3 orang bila dibandingkan dengan analisis hari pertama dan kedua.9 orang mampu membaca selama 31-60 menit.Angka ini menurun bila dibandingkan dengan analisis hari pertama dan kedua sebanyak 1 angka.Dan hanya ada 6 orang yang bisa membaca 61-120 menit, menurun 1 angka.Subyek yang bisa membaca lebih dari 121 menit atau lebih dari 2 jam. Angka ini masih sama seperti pada hasil analisis hari pertama dan kedua.

Peneliti masih semakin yakin kegiatan membaca ini maksimal 30 menit setiap harinya.Karena lebih dari 30 menit dimungkinkan orang sudah tidak konsentrasi untuk membaca.

Data di atas menjelaskan bahwa jumlah halaman yang paling banyak adalah 300 halaman dan paling sedikit adalah 1 halaman.ada perbedaan pada analisis hari pertama diperoleh jumlah halaman paling banyak adalah 200 halaman dan hari kedua 278. Artinya ada peningkatan 32 halaman. Sementara pada jumlah halaman paling sedikit dibaca adalah 1 halaman sama dengan analisis hari kedua.

Persebaran data berdasarkan rentangan halaman (per sepuluh halaman) yang dibaca.Sebanyak 17 orang mampu membaca 1-10 halaman sama dengan data analisis hari pertama. Sementara ada kenaikan level 11-20 halaman sebanyak 13 orang disbanding hari pertama dan kedua.Hanya ada 1 orang yang mampu membaca pada level 21-30 halaman.Kondisi ini terus menurun dibanding analisis hari pertama dan kedua. Pada level membaca 31-40 halaman terjadi penurunan 1 angka yaitu hanya 2 orang. Hanya ada 1 orang 


$$
\text { r.e.c. } 156
$$

yang mampu membaca $>91$ halaman.Artinya kecenderungan orang mampu membaca 10 halaman, sesuai dengan kesimpulan pada hari pertama.

Berdasarkan pemaparan di atas, dapat ditarik kesimpulan bahwa rata-rata orang mampu bertahan membaca selama 30 menit maka jumlah halaman yang dibaca reratanya ada 10 halaman.Untuk membaca 1 halaman dibutuhkan waktu 3 menit.

Berbeda dengan sebaran data tentang efektivitas membaca, yaitu selisih jumlah satuan waktu yang digunakan dengan jumlah halaman yang dibaca. Semakin sedikit waktu yang digunakan untuk membaca halaman maka akan semakin efektif.

Data di atas menjelaskan bahwa ada subyek penelitian yang mampu membaca 176 halaman dalam waktu 110 menit atau keefektifannya berada pada 0,62 menit. Ada penurunan keefektifan ini sebanyak 0,17 menit dibanding analisis hari kedua. Subyek penelitian yang hanya mampu membaca 1 halaman dalam waktu 47 menit, lebih lama dibanding pertama dan kedua, yaitu 27 menit lebih lama.

Berbeda dengan diari baca, diari menulis ini berdasarkan jumlah waktu lama menulis dapat dijelaskan data di atas menunjukkan bahwa waktu paling lama untuk menulis adalah 78 menit atau setara dengan 1 jam lebih 18 menit. Sementara waktu paling pendek adalah 10 menit.Ada waktu sedikit lebih pendek untuk menulis dengan analisis data yang pertama yaitu 2 menit.Jumlah waktu paling pendek menulis selisih 10 menit lebih pendek dari analisis data yang pertama.Angka ini naik 2 angka lebih lama.

\begin{tabular}{|l|l|}
\hline Waktu & Jumlah \\
\hline $0-20$ menit & 13 orang \\
\hline $21-40$ menit & 16 orang \\
\hline $41-60$ menit & 7 orang \\
\hline$>61$ menit & 1 orang \\
\hline Jumlah & 37 orang \\
\hline
\end{tabular}




$$
\text { r.e. }
$$

Data di atas menjelaskan bahwa subyek penelitian yang mampu menulis pada rentang waktu 0-20 menit adalah 13 orang.Angka ini menurun 3 angka.Sementara yang mereka yang mampu menulis pada rentang 21-40 menit sebanyak 16 orang.Angka ini naik 3 angka.Subyek penelitian yang memiliki kemampun menulis dalam rentang 41-60 adalah 7 orang.Sama dengan analisis hari kedua.Serta yang bisa menulis lebih dari 61 menit adalah 1 orang. Data ini sama dengan data sebelumnya.

Jumlah paragrap yang dihasilkan dalam rentangan 5 adalah sebagai berikut:

\begin{tabular}{|l|l|}
\hline Banyak paragrap & Jumlah orang \\
\hline $1-5$ paragrap & 37 orang \\
\hline Jumlah & 37 orang \\
\hline
\end{tabular}

Data ini sama dengan analisis hari kedua subyek penelitian hanya menulis pada rentangan tidak mencapai 5 paragraf.

Berdasarkan jumlah lama waktu menulis dibandingkan dengan banyak paragrap yang dihasilkan dapat diambil kesimpulan.Kecenderungan subyek penelitian mampu menghabiskan waktu menulis selama 0-20 menit dan jumlah paragrap yang dihasilakan adalah 1-5 paragraf.

d. Perbandingan data analisis hari pertama, kedua, dan ketiga

1) Perbandingan lama waktu membaca

Jumlah waktu yang paling lama membaca adalah pada hari kedua sebanyak 1922. Jumlah rata-rata baca dari masing masing hari subyek penelitian sebanyak 1813 atau setara dengan 30 jam lewat 21 menit. Sementara rata-rata subyek penelitian membaca setiap harinya adalah 49 menit.Artinya untuk kegiatan membaca ini perlu dibatasi tidak lebih dari 49 menit perharinya.Untuk lebih jelasnya perhatikan paparan data di bawah ini.

Perbandingan rentangan lama waktu:

\begin{tabular}{|l|c|c|c|}
\hline Waktu & Hari pertama & Hari kedua & Hari ketiga \\
\hline $0-30$ menit & 18 orang & 18 orang & 21 orang \\
\hline $31-60$ menit & 9 orang & 10 orang & 9 orang \\
\hline
\end{tabular}




\begin{tabular}{|l|c|c|c|}
\hline $61-120$ & 8 orang & 7 orang & 6 orang \\
\hline$>121$ & 2 orang & 2 orang & 1 orang \\
\hline Jumlah & 37 orang & 37 orang & 37 orang \\
\hline
\end{tabular}

Rata-rata kemampuan membaca subyek penelitian berada pada rentangan 0-30 menit. Artinya model membaca ini perharinya bertahap mulai dari 5 menit, 10 menit, 15 menit, 20 menit, 25 menit, dan 30 menit.Hal ini untuk membiasakan subyek penelitian memiliki semangat membaca.

2) Perbandingan banyak halaman

Data di atas menunjukkan bahwa jumlah halaman yang paling banyak di baca adalah pada hari kedua sebanyak 1329 halaman. Jumlah keseluruhan halaman yang dibaca selama 3 hari adalah 3159,5 halaman. Rata-rata perhari subyek penelitian mampu membaca 28,46 halaman.

Jika digabungkan antara jumlah waktu membaca dengan banyak halaman maka diperoleh sebuah urutan sebagai berikut:

\begin{tabular}{|c|c|c|}
\hline Hari Ke- & Waktu & Rentang Halaman \\
\hline 1 & 5 menit & $1-4$ halaman \\
\hline 2 & 10 menit & $5-9$ halaman \\
\hline 3 & 15 menit & $10-14$ halaman \\
\hline 4 & 20 menit & $15-19$ halaman \\
\hline 5 & 25 menit & $20-24$ halaman \\
\hline 6 & 30 menit & $25-29$ halaman \\
\hline
\end{tabular}

Hal ini dengan asumsi bahwa untuk membaca 1 halaman diperlukan 1,25 menit. Sebaran data berdasarkan rentangan halaman (per sepuluh halaman) yang dibaca:

\begin{tabular}{|c|c|c|c|}
\hline banyak halaman & Hari Pertama & Hari Kedua & Hari ketiga \\
\hline $1-10$ & 17 orang & 20 orang & 17 orang \\
\hline $11-20$ & 11 orang & 5 orang & 13 orang \\
\hline
\end{tabular}




\begin{tabular}{|c|c|c|c|}
\hline \multicolumn{5}{|c}{159} & 3 orang & 1 orang \\
\hline $21-30$ & 2 orang & 3 orang & 2 orang \\
\hline $31-40$ & 3 orang & 3 orang & \\
\hline $41-50$ & 1 orang & & \\
\hline $51-60$ & 0 orang & & \\
\hline $61-70$ & 0 orang & & \\
\hline $71-80$ & 0 orang & & \\
\hline $81-90$ & 0 orang & & 2 orang \\
\hline $91-100$ & 1 orang & 1 orang & \\
\hline$>101$ & 2 orang & 5 orang & \\
\hline Jumlah & 37 orang & 37 orang & 37 orang \\
\hline
\end{tabular}

Dengan asumsi bahwa rata-rata orang memiliki kemampuan membacanya adalah 1-10 halaman maka kegiatan bertahap itu menjadi keharusan.

3) Perbandingan efektivitas membaca

Efektivitas membaca subyek penelitian adalah pada level 4,78 menit. Artinya rata-rata untuk membaca satu halaman dibutuhkan waktu 4,78 menit. Hal ini sejalan dengan urutan waktu membaca dengan banyak halaman yang harus dibaca.

4) Perbandingan lama waktu menulis

Data di atas menunjukkan bahwa jumlah waktu selama tiga hari untuk menulis yang dilakukan oleh 37 subyek penelitian ini sebanyak 3253 menit atau setara dengan 54 jam lebih 21 menit. Rata-rata jumlah keseluruhan waktu yang diperlukan untuk menulis adalah pada level 29,30 menit.

\begin{tabular}{|c|c|c|c|}
\hline Waktu & Hari pertama & Hari kedua & Hari ketiga \\
\hline $0-20$ menit & 3 orang & 16 orang & 13 orang \\
\hline $21-40$ menit & 30 orang & 13 orang & 16 orang \\
\hline $41-60$ menit & 3 orang & 7 orang & 7 orang \\
\hline
\end{tabular}




\begin{tabular}{|c|c|c|c|}
\hline \multicolumn{4}{|c}{ recer } \\
\hline Jumlah & 161 orang & 1 orang & 1 orang \\
\hline 37 orang & 37 orang & 37 orang \\
\hline
\end{tabular}

Sesuai dengan hasil rata-rata waktu menulis pada level 29,30 menit maka ini sesuai dengan pada tabel di atas. Kecenderungan orang menulis itu pada rentang waktu 21-40 menit.

5) Perbandingan banyak paragraf

Data di atas menunjukkan jumlah paragarp yang mampu ditulis oleh 37 subyek penelitian sebanyak 333 paragrap.Artinya setiap subyek penelitian dalam 3 hari menghasilkan 9 paragrap.Setiap hari rata-rata menulis 3 paragrap.

Jika digabungkan antara jumlah waktu menulis dengan banyak paragrap maka diperoleh sebuah urutan sebagai berikut:

\begin{tabular}{|c|c|c|}
\hline Hari Ke- & Waktu & Rentang Halaman \\
\hline 1 & $1-9$ menit & $1-3$ Paragrap \\
\hline 2 & $10-18$ menit & $4-6$ Paragrap \\
\hline 3 & $19-27$ menit & 7-9 Paragrap \\
\hline 4 & $27-36$ menit & $10-19$ Paragrap \\
\hline
\end{tabular}

e. Analisis Hari Keempat Diari Berbagi

Waktu yang digunakan dalam berbagi rata-rata adalah 54,89 menit dengan jumlah peserta 167 orang. Sebanyak 161 orang menyatakan kegiatan ini positif dan 6 orang menyatakan kegiatan ini negatif.Lama waktu berbagi paling panjang adalah 300 menit setara dengan 5 jam. Dan paling sedikit adalah 10 menit.

Jumlah responden terbanyak adalah sebelas orang.Dan jumlah peserta paling sedikit adalah 3 orang.Sementara respon positif yang diperoleh sebanyak 161 dan negatif sebanyak 6 orang.

Berdasarkan pemaparan semua data di atas dapat dibuat sebuah kesimpulan yang tentang model baca, tulis, dan bagi sebagai berikut:

1) Pelaksanaan model ini harus secara bertahap

2) Setiap orang dapat mencoba dengan memulai urutan

3) Model yang dapat diambil adalah dengan konsisten menaikkan kemampuannya. Jika dalam beberapa hari belum ada kenaikan 


$$
\text { recos }
$$

maka minimal bisa berlatih sebanyak 3 hari untuk naik pada level berikutnya.

4) Model yang diikuti adalah sebagai berikut

\begin{tabular}{|c|c|c|c|}
\hline Hari Ke- & Waktu & $\begin{array}{c}\text { Rentang } \\
\text { Halaman }\end{array}$ & Level \\
\hline 1 & 5 menit & $1-4$ halaman & Dasar 1 \\
\hline 2 & 10 menit & $5-9$ halaman & Dasar 2 \\
\hline 3 & 15 menit & $10-14$ halaman & Menengah 1 \\
\hline 4 & 20 menit & $15-19$ halaman & Menengah 2 \\
\hline 5 & 25 menit & $20-24$ halaman & Atas 1 \\
\hline 6 & 30 menit & $25-29$ halaman & Atas 2 \\
\hline
\end{tabular}

5) Untuk menerapkan diari menulis dapat menggunakan acuan sebagai berikut:

\begin{tabular}{|c|c|c|}
\hline Hari Ke- & Waktu & Rentang Halaman \\
\hline 1 & $1-9$ menit & 1-3 Paragrap \\
\hline 2 & $10-18$ menit & 4-6 Paragrap \\
\hline 3 & $19-27$ menit & 7-9 Paragrap \\
\hline 4 & $27-36$ menit & 10-19 Paragrap \\
\hline
\end{tabular}

6) Kegiatan berbagi dapat dilakukan dengan jumlah minimal 3 peserta. Dengan berbagi maka secara tidak langsung menumbuhkan kemandirian dan kepercayaan diri masing-masing orang.

\section{Simpulan}

Penelitian ini dapat mendapat dua simpulan :

1. Model "Baca, Tulis, dan Bagi" dalam penguatan literasi adalah terdiri dari tiga kegiatan yaitu :

a. Kegiatan membaca dengan diari baca 


$$
\text { recus }
$$

b. Kegiatan menulis dengan diari menulis

c. Kegiatan berbagi dengan diari berbagi

setiap kegiatan memiliki tahapan sebagai berikut:

a. Tahap I : Persiapan

b. Tahap II : Pelaksanaan

c. Tahap III: Analisis

2. Penerapan Model "Baca, Tulis, dan Bagi" dalam penguatan literasi pada Mahasiswa Pendidikan Guru Madrasah Ibtidaiyah STAIN Pamekasan diperoleh sebuah simpulan

a. Kegiatan baca

\begin{tabular}{|c|c|c|c|}
\hline Hari Ke- & Waktu & $\begin{array}{c}\text { Rentang } \\
\text { Halaman }\end{array}$ & Level \\
\hline 1 & 5 menit & $1-4$ halaman & Dasar 1 \\
\hline 2 & 10 menit & $5-9$ halaman & Dasar 2 \\
\hline 3 & 15 menit & $10-14$ halaman & Menengah 1 \\
\hline 4 & 20 menit & $15-19$ halaman & Menengah 2 \\
\hline 5 & 25 menit & $20-24$ halaman & Atas 1 \\
\hline 6 & 30 menit & $25-29$ halaman & Atas 2 \\
\hline
\end{tabular}

b. Kegiatan menulis

\begin{tabular}{|c|c|c|}
\hline Hari Ke- & Waktu & Rentang Halaman \\
\hline 1 & $1-9$ menit & 1-3 Paragrap \\
\hline 2 & $10-18$ menit & 4-6 Paragrap \\
\hline 3 & $19-27$ menit & 7-9 Paragrap \\
\hline 4 & $27-36$ menit & 10-19 Paragrap \\
\hline
\end{tabular}

c. Kegiatan berbagi dapat dilakukan minimal 3 orang peserta 


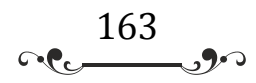

\section{Daftar Pustaka}

A. Khozin Afandi. 2006.Berpikir Teoritis Merancang Proposal. Surabaya: Pascasarjana IAIN Sunan Ampel Surabaya.

Abd. al-Rahman dan Ahmad Usman. t.t. Manahij Al-Bahts Al-'ilm Wa Turuq Al-Kitabah. Beirut: Dar al-Fikr.

Alfandi, M. 2016. "Program Literasi Media Televisi Untuk Penguatan Minat Baca Siswa." Dimas: Jurnal Pemikiran Agama Untuk Pemberdayaan 16, no. 2: 333-350.

Andi, Supiandi. 2017. "Menumbuhkan Budaya Literasi Dengan Menggunakan 'Program Kata' Di SMA Muhammadiyah Toboali Kab. Bangka Selatan." STUDIA 1, no. 1: 93-106.

Arikunto, Suharsimi. t.t.Prosedur Penelitian: Suatu Pendekatan Praktik. Jakarta: Rineka Cipta.

Arohman, Mamat, Saefudin Saefudin, and Didik Priyandoko. 2016. "Kemampuan Literasi Sains Siswa Pada Pembelajaran Ekosistem." In Prosiding Seminar Biologi, 13: 90-92. http://www.jurnal.fkip.uns.ac.id/index.php/prosbio/article/ view/9480.

Burhan Nurgiantoro. 1988.Penilaian Dalam Pengajaran Bahasa Dan Sastra. Yogyakarta: BPFE.

Djago Tarigan, H.G. Tarigan. 1986.Teknik Pengajaran Keterampilan Berbahasa. Bandung: Penerbit Angkasa.

DP Tampubolon. 1987. Kemampuan Membaca: Teknik Membaca Efektif Dan Efisien. Bandung: Angkasa.

Gipayana, Muhana. "Pengajaran Literasi Dan Penilaian Portofolio Dalam Konteks Pembelajaran Menulis Di SD." Jurnal Ilmu Pendidikan 11, no. 1 (2016). http://journal.um.ac.id/index.php/jip/article/view/87.

Harjasujana, Harjasujana. 2003.Membaca Dalam Teori Dan Praktik. Bandung: Mutiara, 2003. 


$$
\text { r.e. }
$$

Henri Guntur Tarigan. 1984.Membaca Sebagai Suatu Keterampilan Berbahasa. Bandung: Angkasa.

Jusmiana, Andi, Sumarni Susilawati, and Fahrul Basir. 2016. "Deskripsi Trajektori Berpikir Siswa Dalam Menyelesaikan Masalah Literasi Matematika." Prosiding 2, no. 1. http://journal.uncp.ac.id/index.php/proceding/article/view/ 374.

Karyanto, Puguh. 2014. "Penguatan Modal Manususia Dan Peningkatan Literasi Ekologi Melalui Pedagogi Spesifik Materi: Pengembangan Model Dalam Pembelajaran Ekologi Melalui Penelitia Ekofisiologi Tikus Sawah." In Proceeding Biology Education Conference: Biology, Science, Enviromental, and Learning, Vol. https://jurnal.uns.ac.id/prosbi/article/view/7834.

Kridalaksana, Harimurti. Tata Bahasa Deskriptif Bahasa Indonesia: Sintaksis. Jakarta: Pusat Pembinaan den Pengembangan Bahasa, n.d.

Lexy J. Moleong. 2005.Metodologi Penelitian Kualitatif (Edisi Revisi). Bandung: Remaja Rosda Karya.

M. Atar Semi. 2007.Dasar-Dasar Keterampilan Menulis. Bandung: Angkasa.

Miharja, Fuad Jaya. 2016. "Literasi Islam\& Literasi Sains Sebagai Penjamin Mutu Kualitas Manusia Indonesia Di Era Globalisasi." Research Report, no. 2. http://researchreport.umm.ac.id/index.php/researchreport/article/view/681.

Naibaho, Kalarensi. 2007. "Menciptakan Generasi Literat Melalui Perpustakaan." Visi Pustaka 9, no. 3: 1-8.

NK, Johanes Edo, Raymundus Rikang RW, and Cornel Dimas SK. 2013. "Literasi Kaum Muda Tentang Good Governance Melalui Isu Korupsi Di Televisi." Jurnal ILMU KOMUNIKASI 9, no. 1. https://ojs.uajy.ac.id/index.php/jik/article/view/186. 


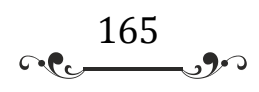

Purwanti, Elly, and Wahyu Prihanta. 2016. "Penguatan Literasi Ekosistem Pada Siswa Klas X Dengan Specific Materi: Pembelajaran Ekosistem Melalui Penelitian Ekofisiologi Hutan Mangrove." Research Report, 155-163.

Rahayu, Triwati. 2016. "Penumbuhan Budi Pekerti Melalui Gerakan Literasi Sekolah". https://publikasiilmiah.ums.ac.id/handle/11617/7644.

Seya Yuwana Sudikan. 2001.Metode Penelitian Kebudayaan. Surabaya: Universitas Negeri Surabaya Press.

Solehan T.W dkk. 2008.Pendidikan Bahasa Indonesia Di SD. Jakarta: Universitas Terbuka.

St. Y., Slamet. 2008.Dasar-Dasar Pembelajaran Bahasa Dan Sastra Indonesia Di Sekolah Dasar. Surakarta: UNS Press.

Sumarno. 2009. Pembelajaran Menulis. Jakarta: Departemen Pendidikan Nasional.

Sutrisno Hadi. 1989. Metodologi Research. Yogyakarta: Andi Offset.

Syafi'ie, Imam. 1999.Pengajaran Membaca Terpadu. Malang: IKIP.

Tobroni, Imam Suprayogo. 2001.Metodologi Penelitian Sosial-Agama. Bandung: Remaja Rosda Karya.

Yore, Larry D., and David F. Treagust. 2006. "Current Realities and Future Possibilities: Language and Science Literacyempowering Research and Informing Instruction." International Journal of Science Education 28, no. 2-3 (February 15, 2006): 291-314. doi:10.1080/09500690500336973. 